\title{
Serum uric acid in hypertensive patients
}

\author{
C. J. Bulpitt \\ From the Department of Clinical Pharmacology, Royal Postgraduate Medical School; and Department of \\ Medical Statistics and Epidemiology, London School of Hygiene and Tropical Medicine
}

Both the average serum uric acid and annual increment were determined in 250 treated patients attending a hypertension clinic. The average serum uric acid was greater in men compared with women, in patients receiving a thiazide diuretic and in patients with a high average plasma urea. The mean annual increment in uric acid was close to zero ( 0.0017 momol/litre per year) and was not related to sex, age, blood pressure control, diuretic therapy, or plasma urea. There was an unexplained positive association between annual increment and methyldopa therapy though this drug was not associated with a significantly high average serum uric acid.

$A$ table is presented giving the theoretical upper limits for average serum uric acid according to sex, plasma urea concentration, and whether or not a thiazide diuretic has been prescribed. It is hoped that this table will be of assistance in assessing the normality or otherwise of a high serum uric acid found in a hypertensive patient.

Hyperuricaemia is a common finding in hypertensive patients (Breckenridge, 1966) and may lead to difficulty in clinical management. After detecting a high serum uric acid concentration and in the absence of a history of gout, the clinician may be uncertain whether to prescribe (or to stop prescribing) a drug known to increase the serum uric acid concentration.

Surveys of the general population have revealed many subjects with a high serum uric acid but no clinical gout (Popert and Hewitt, 1962). Subjects with hyperuricaemia do, however, have an increased incidence of gout (O'Sullivan, 1968) and the clinician may be able to prescribe more confidently if he can calculate whether the serum uric acid for a particular patient is higher than expected. The serum uric acid depends on many variables (Acheson and Chan, 1969; Cannon et al., 1966), and a single upper limit for a 'normal' result cannot be defined. This paper, therefore, investigates the relation between serum uric acid in hypertensive patients and the treatment given, sex, age, blood pressure, and renal function. The results presented allow the clinician to assess the 'normality' or otherwise of a serum uric acid measurement, and also the likely effect of his prescriptions on uric acid concentration.

Received 5 June 1975.

\section{Patients and methods}

\section{Patients}

The case records of all patients attending the Hammer smith Hospital hypertension clinic during a three-month period between November 1970 and January 1971 were examined. 250 patients were selected as having been seen at the clinic for a period of at least 5 years, and having had at least 4 measurements of plasma urea and at least one measurement of serum uric acid.

Information recorded included sex, age, diagnosis, hypotensive treatment given, the plasma urea and serum uric acid measurements, and corresponding dates. Any in-hospital measurements after a surgical operation were omitted.

Of the 250 patients, $77 \mathrm{had}$ been diagnosed as having hypertension possibly 'secondary' to a renal pathology: 23 of these patients had chronic pyelonephritis, $6 \mathrm{had}$ renal calculi, 6 had renal artery stenosis, 10 had only a single kidney, and the remainder had a variety of renal lesions. The patients had an average follow-up period of 7 years during which a mean of 12 plasma urea and 5 uric acid estimations were made. A subset of 119 patients who attended over a 6-week period had their average standing blood pressure computed from the time of first attending the clinic.

\section{Biochemical methods}

All biochemical measurements were made in the Department of Chemical Pathology, at the Royal Postgraduate Medical School. The plasma urea was measured by the diacetyl monoxime method, using the autoanalyser after 1958, and the serum uric acid by the non-automated uricase method before 1965, the 
automatic technicon phosphotungstate reduction method, using cyanide from 1965 to 1967 , and carbonate from 1968.

\section{Statistical methods}

The biochemical data were examined for statistical normality. The serum uric acid (in $\mathrm{mmol} / \mathrm{l}$ ) was distributed normally but plasma urea (in $\mathrm{mmol} / \mathrm{l}$ ) had a lognormal distribution and was converted to a normal distribution by taking the logarithm of each observation. As in many instances the patients had more than one measurement in a year, the averages (arithmetic means) of the transformed plasma ureas and uric acids were calculated for each patient and each year, together with the corresponding average dates. From these data the average uric acid, log urea, and age were computed for the period of follow-up.

One hundred and ninety-three patients had at least three estimations of uric acid in different years and the annual increment in uric acid was computed by a least squares regression of the yearly averages on time.

The independent effects on average uric acid and annual increment, of age, sex, average blood pressure during treatment, mean plasma urea, and treatment were computed in these 193 patients using standard multiple regression techniques. Theoretical confidence limits for the observed data were calculated by the standard method (Armitage, 1971).

The average age of the patients during follow-up ranged from 20 to 71 years. The mean plasma urea from 0.3 to $1.1 \log \mathrm{mmol} / \mathrm{l}$, average standing systolic pressure from 120 to $193 \mathrm{mmHg}(16.0$ to $25.7 \mathrm{kPa}$ ), and average standing diastolic pressure from 76 to $116 \mathrm{mmHg}$ $(10 \cdot 1$ to $15.4 \mathrm{kPa})$.

\section{Results}

Table 1 lists the average serum uric acid during follow-up and the annual increment in uric acid according to sex and the type of hypertension. Men had a higher average uric acid than women $(\mathbf{P}<$ 0.001 ) but the annual increment was not significantly different between the sexes $(P=0 \cdot 2)$. The overall annual increment in uric acid was small at 0.0017 $\mathrm{mmol} / \mathrm{l}$ and not significantly different from zero, 45 per cent of patients having a fall or no rise in uric acid with time. The average serum uric acid and annual increment were not significantly different in essential and 'secondary' hypertension.

The overall range of average uric acid was $0 \cdot 17$ to $0.57 \mathrm{mmol} / \mathrm{l}$, with standard deviation 0.08 , and the annual increment ranged from -0.06 to +0.08 mmol/l per year, standard deviation 0.02 .

\section{Effect of treatment}

Table 2 lists the average uric acid during follow-up and the average annual increment in uric acid, sub- divided according to whether a particular hypotensive treatment was given or not, and whether a potassium-losing diuretic was prescribed. Patients taking more than one potent hypotensive agent are included. The potassium-losing diuretics were thiazide compounds with the exception of 7 patients taking mainly frusemide, 1 patient taking ethacrynic acid, and 2 patients receiving chlorthalidone. The administration of a diuretic was associated with a $0.05 \mathrm{mmol} / 1(1 \mathrm{mg} / 100 \mathrm{ml})$ excess in average serum uric acid. Many patients were on a diuretic when first attending the clinic, perhaps explaining why the annual increment was not significantly increased in patients taking these drugs. Guanethidine therapy was associated with raised levels of uric acid (an increase of $0.03-0.05 \mathrm{mmol} / \mathrm{l}$ over groups not taking this drug). This was because of the positive association of serum uric acid with plasma urea. Guanethidine increased the plasma urea in these patients (Bulpitt, 1974) and, when this effect was allowed for, guanethidine had no additional effect on uric acid. Methyldopa plus diuretic therapy was not associated with a high average serum uric acid but was associated with a high annual increment $(0.004 \mathrm{mmol} / \mathrm{l}$ per year for all patients given the drug, against $-0.003 \mathrm{mmol} / 1$ per year for those not taking the drug, $P<0.05)$. The analysis was repeated for patients taking methyldopa for at least two-thirds of the study period and who were not taking any other hypotensive drug apart from a thiazide diuretic. These 48 patients again had an average annual increment of $0.004 \mathrm{mmol} / 1$ per year. Reserpine was associated with a similar high annual increment, but more detailed examination of a 'reserpine only' group did not support a high annual increase with this drug.

\section{Relation between uric acid on treatment and other variables}

The effects on the average uric acid of renal function (as assessed by the plasma urea), age, sex, average blood pressure when computed, and the treatment given, were examined simultaneously using multiple regression techniques. Age, average standing systolic and diastolic pressure, and the presence of methyldopa, bethanidine, guanethidine, or reserpine therapy did not have any independent effect on the average uric acid.

Regression of the average serum uric acid during treatment $(Y)$ on sex $(S, O=$ female, $1=$ male), the mean $\log$ urea during follow-up ( $\mathrm{L}$ in $\log \mathrm{mmol} / \mathrm{l}$ ), and treatment given (e.g. $\mathrm{D}=$ potassium-losing diuretic, $\mathrm{O}=$ not given, $1=$ given for less than twothirds of the follow-up period, and $2=$ given for 
TABLE 1 Average serum uric acid (mmol/l) and annual increment (mmol/l per year) according to type of hypertension, and sex



Conversion SI to traditional units serum uric acid: $1 \mathrm{mmol} / 1 \approx 16.8 \mathrm{mg} / 100 \mathrm{ml}$.

TABLE 2 Average uric acid concentration and annual increment according to whether therapy given or not during study period; both men and women, and essential and 'secondary' hypertension

\begin{tabular}{|c|c|c|c|c|c|}
\hline Drug & $\begin{array}{l}\text { Drug not given } \\
\text { no diuretic }\end{array}$ & $\begin{array}{l}\text { Drug not given } \\
\text { diuretic given }\end{array}$ & $\begin{array}{l}\text { Drug given } \\
\text { no diuretic }\end{array}$ & $\begin{array}{l}\text { Drug given } \\
\text { diuretic given }\end{array}$ & $\begin{array}{l}\text { Drug/no drug } \\
\text { comparison }\end{array}$ \\
\hline \multicolumn{6}{|c|}{ Average serum uric acid (mmol/l) } \\
\hline Methyldopa & $0.334(8)$ & $0 \cdot 369(65)$ & $0 \cdot 314(16)$ & $0.376(161)$ & NS \\
\hline Bethanidine & $0.321(21)$ & $0.373(172)$ & $0.316(3)$ & $0.376(54)$ & NS \\
\hline Guanethidine & $0.310(19)$ & $0.368(185)$ & $0.359(5)$ & $0.401(41)$ & $P<0.05$ \\
\hline Reserpine & $0.318(19)$ & $0.380(106)$ & $0.330(5)$ & $0.354(57)$ & NS \\
\hline Any drug & - & - & $0 \cdot 320(24)$ & $0 \cdot 374(226)$ & $P<0.01$ \\
\hline \multicolumn{6}{|c|}{ Annual increase in serum uric acid (mmol/l per year) } \\
\hline Methyldopa & $0.0003(6)$ & $-0.0033(47)$ & $0.0001(14)$ & $0.0037(126)$ & $P<0.05$ \\
\hline Bethanidine & $0.0001(17)$ & $0.0014(129)$ & $0.0004(3)$ & $0.0030(44)$ & NS \\
\hline Guanethidine & $-0.0007(16)$ & $0.0023(138)$ & $0.0035(4)$ & $0.0003(35)$ & NS \\
\hline Reserpine & $0.0000(15)$ & $0.0012(133)$ & $0.0004(5)$ & $0.0038(40)$ & NS \\
\hline Any drug & - & - & $0.0001(20)$ & $0.0018(173)$ & NS \\
\hline
\end{tabular}

Conversion SI to traditional units serum uric acid: $1 \mathrm{mmol} / 1 \approx 16.8 \mathrm{mg} / 100 \mathrm{ml}$.

more than two-thirds of the time): yielded the following equation:

$$
\mathrm{Y}=0 \cdot 122+0 \cdot 041 \mathrm{~S}+0 \cdot 018 \mathrm{D}+0 \cdot 263 \mathrm{~L} \ldots(1)
$$

( $n=190$, Multiple $R=0.55$, sex and log urea regression coefficients significant at the $0.1 \%$ level, and the diuretic regression coefficient at the $5 \%$ level). Age could only be excluded from the equation at the 9 per cent level.

Equation (1) explained 30 per cent of the variation in uric acid on the basis of sex, plasma urea, and the administration of a diuretic. The administration of long-term diuretic therapy increased the serum uric acid by $0.036 \mathrm{mmol} / 1$ independently of renal function, and men will have a serum uric acid $0.041 \mathrm{mmol} / 1$ higher than women after adjusting for plasma urea.

\section{Expected results for a hypertensive patient}

Table 3 lists the average uric acid concentration theoretically exceeded by 5 per cent and 1 per cent of the patients, derived from equation (1). As an example, 5 per cent of women with a plasma urea of $4 \mathrm{mmol} / \mathrm{l}$ who do not take a diuretic, may have a uric acid averaging more than $0.39 \mathrm{mmol} / 1$ (6.6 $\mathrm{mg} / 100 \mathrm{ml}$ ), whereas 5 per cent of men taking a diuretic and with a plasma urea of $8 \mathrm{mmol} / 1$ may have an average uric acid of over $0.55 \mathrm{mmol} / \mathrm{l}$ 
TABLE 3 Average serum uric acid concentrations (mmol/l) exceeded by theoretical 5 and 1 per cent of Hammersmith Clinic patients, according to average plasma urea, sex, and whether diuretic given continuously or not at all

\begin{tabular}{|c|c|c|c|c|c|c|c|c|}
\hline \multirow{2}{*}{$\begin{array}{l}\text { Plasma } \\
\text { urea } \\
\text { ( mmol/l) }\end{array}$} & \multicolumn{2}{|c|}{$\begin{array}{l}\text { Men } \\
\text { No diuretic }\end{array}$} & \multicolumn{2}{|c|}{ Diuretic } & \multicolumn{2}{|c|}{$\begin{array}{l}\text { Women } \\
\text { No diuretic }\end{array}$} & \multicolumn{2}{|c|}{ Diuretic } \\
\hline & $5 \%$ & $1 \%$ & $5 \%$ & $1 \%$ & $5 \%$ & $1 \%$ & $5 \%$ & $1 \%$ \\
\hline $\begin{array}{r}2 \\
4 \\
8 \\
16\end{array}$ & $\begin{array}{l}0.36 \\
0.44 \\
0.52 \\
0.59\end{array}$ & $\begin{array}{l}0.39 \\
0.47 \\
0.55 \\
0.62\end{array}$ & $\begin{array}{l}0.39 \\
0.47 \\
0.55 \\
0.63\end{array}$ & $\begin{array}{l}0.42 \\
0.50 \\
0.58 \\
0.66\end{array}$ & $\begin{array}{l}0.31 \\
0.39 \\
0.47 \\
0.55\end{array}$ & $\begin{array}{l}0.34 \\
0.42 \\
0.50 \\
0.58\end{array}$ & $\begin{array}{l}0.35 \\
0.43 \\
0.51 \\
0.59\end{array}$ & $\begin{array}{l}0.38 \\
0.46 \\
0.54 \\
0.62\end{array}$ \\
\hline
\end{tabular}

Conversion SI to traditional units serum uric acid $1 \mathrm{mmol} / 1 \approx 16.8 \mathrm{mg} / 100 \mathrm{ml}$ plasma urea $1 \mathrm{mmol} / 1 \approx 6.0 \mathrm{mg} / 100 \mathrm{ml}$.

$(9 \cdot 2 \mathrm{mg} / 100 \mathrm{ml})$. Such a man with a uric acid concentration of $0.55 \mathrm{mmol} / 1$ can be regarded as within the expected range and similarly if not on a diuretic, $0.52 \mathrm{mmol} / 1$ would lie within this range.

\section{Discussion}

Forty-eight per cent of the hypertensive men on treatment and 40 per cent of the women had an average serum uric acid greater than $0.42 \mathrm{mmol} / 1$ $(7 \mathrm{mg} / 100 \mathrm{ml})$ and $0.36 \mathrm{mmol} / 1(6 \mathrm{mg} / 100 \mathrm{ml})$, respectively. These values have been considered abnormal (Breckenridge, 1966), but in only 3 per cent of the patients had either a diagnosis of gout been made or treatment given to lower the serum uric acid.

Many subjects with high serum uric acid concentrations do not develop gout (Popert and Hewitt, 1962 ) and in the presence of renal failure, Bywaters and Glynn (1970) report patients with concentrations of up to $2.4 \mathrm{mmol} / 1$ yet without clinical gout. Thiazide, diuretics, and frusemide have been shown to increase the serum uric acid (Dinon, Kim, and Vander Veer, 1958; Kerr and Robson, 1965), and there are case reports of attacks of gout with both chlorothiazide (Oren, Rich, and Belle, 1958; Aronoff, 1960; Warshaw, 1960) and frusemide (Humphreys, 1966).

It is, therefore, possible that diuretics increase the incidence of gout but proof is awaited from longterm controlled trials. For the present, two possible strategies present themselves in the absence of clinical gout; diuretics can either be withheld when the serum uric acid concentration exceeds an arbitrary fixed 'normal' level or when the upper limits presented in Table 3 are exceeded. These two approaches have to be tested in the clinical situation as the place of treatment for asymptomatic hyperuricaemia has yet to be determined. Seegmiller (1967) has suggested treatment for sustained levels greater than $0.54 \mathrm{mmol} / \mathrm{l}$ regardless of its cause. The confidence limits in Table 3 will not be exactly reproduced in studies of other hypertensive populations. If equation (1) can be improved to explain more of the variation in uric acid then the confidence limits can be more precisely defined. This may be achieved by adding further significant variables; for example it may be possible to incorporate weight and haemoglobin.

Equation (1) shows that diuretic therapy has an effect on the serum uric acid over and above any rise in plasma urea that this therapy may produce. Similarly, the excess uric acid concentration in men cannot be explained on the basis of the sex difference in plasma urea concentration.

The sex difference is associated with a reduction, in men, of the urate clearance rate per unit of surface area, in the presence of an increased male glomerular filtration rate (Smyth, Stecher, and Wolfson, 1948), and the present finding supports a sex effect on serum uric acid concentration independent of that on plasma urea.

Guanethidine was shown to be associated with a high uric acid via the effect of this drug on plasma urea. In other words, the mechanism for increasing serum uric acid was the same as the action in increasing plasma urea. It has been suggested that this mechanism is the fall in renal blood flow in the upright position (Bulpitt, 1974) and this effect could also explain the hyperuricaemic action of pempidine and mecamylamine reported by Dollery, Duncan, and Schumer (1960). The additional effect of diuretics over and above the effect on plasma urea would be expected from the effect on renal tubular function produced by these agents.

In a smaller survey of guanethidine treated patients, Fry and Barlow (1962) did not find increased serum uric acid concentrations. Similarly, Daley and Evans (1962) were unable to detect a hyperuricaemic action when methyldopa was ad- 
ministered. The finding in the present study of a raised annual increment in uric acid with methyldopa without a significant increase in average uric acid remains unexplained.

Cannon et al. (1966) considered that an impairment of renal function will raise the serum uric acid far more commonly than an increased uric acid will cause renal damage. In this paper the serum uric acid has, therefore, been predicted using the logarithm of plasma urea and not the other way about. Acheson and Chan (1969) have predicted the serum uric acid in the normal population using weight, age, total serum protein, haemoglobin, and sex. They explained 38 per cent of the variation in serum uric acid. Equation (1) in hypertensive patients explained 30 per cent of the variation in uric acid on the basis of diuretic treatment, sex, and plasma urea. After standardizing for triglyceride concentration, Zalokar et al. (1974) reported a significant relation between serum uric acid and blood urea in a normal population. The relation between these two biochemical variables was not as close as in the hypertensive patients described in the present study. In fact the zero order correlation coefficient for the normal population was only 0.01 and non-significant, against $0.47(P<0.001)$ in hypertensive patients. This can be explained on the basis of abnormal renal function in hypertension, assuming the normally functioning kidney can handle uric acid and urea with a greater independence. For example, tubular secretion of uric acid by a normal kidney (Gutman, Yu, and Berger, 1959) may produce a dissociation between the plasma concentrations of uric acid and urea in normal subjects, assuming secretion of urea by a different mechanism (Schmidt-Nielsen, 1958). If tubular function is impaired similar mechanisms for filtration and reabsorption of both urea and uric acid may ensure a positive and statistically highly significant association between plasma uric acid and urea concentrations. Studies on untreated hypertensive patients at presentation to hospital confirm that this association is not caused by treatment. The correlation coefficients between log plasma urea and serum uric acid for men and women with untreated essential hypertension and men and women with possible secondary hypertension are respectively $+0.35,0.44,0.38$, and 0.48 (Bulpitt, 1972).

I am indebted to Professor I. Wootton and his department of Chemical Pathology where all the biochemical tests reported in this survey were carried out, and to Professor C. T. Dollery for advice and encouragement.

The work was supported in part by the Medical Research Council and the Department of Health and Social Security.

\section{References}

Acheson, R. M., and Chan, Y.-K. (1969). The prediction of serum uric acid in a general population. Fournal of Chronic Diseases, 21, 543.

Armitage, P. (1971). Statistical Methods in Medical Research, p. 164. Blackwell, Oxford and Edinburgh.

Aronoff, A. (1960). Acute gouty arthritis precipitated by chlorothiazide. New England fournal of Medicine, 262, 767.

Breckenridge, A. (1966). Hypertension and hyperuricaemia. Lancet, $1,15$.

Bulpitt, C. J. (1972). Unpublished observations presented in a Dissertation towards the Degree of Master of Science (Medical Statistics). University of London.

Bulpitt, C. J. (1974). Blood urea changes in hypertensive patients according to therapy given, blood pressure control, and serum potassium levels. British Heart fournal, 36, 383.

Bywaters, E. G. L., and Glynn, L. E. (1970). Connective tissue disorders. In Biochemical Disorders in Human Disease, 3rd ed., p. 735. Ed. by R. H. S. Thompson and I. D. P. Wootton. Churchill, London.

Cannon, P. J., Stason, W. B., Dermartini, F. E., Sommers, S. C., and Laragh, J. H. (1966). Hyperuricemia in primary and renal hypertension. New England fournal of Medicine, 275, 457.

Daley, D., and Evans, B. (1962). Another hypotensive agent -methyldopa. British Medical fournal, 2, 156.

Dinon, L. R., Kim, Y. S., and Vander Veer, J. B. (1958). Clinical experience with chlorothiazide (Diuril) with particular emphais on untoward responses. A report of 121 cases studied over a 15-month period. American fournal of the Medical Sciences, 236, 533.

Dollery, C. T., Duncan, H., and Schumer, B. (1960). Hyperuricaemia related to treatment of hypertension. British Medical fournal, 2, 832.

Fry, L., and Barlow, K. A. (1962). Serum uric acid levels in hypertensive patients treated with guanethidine. British Medical fournal, 1, 920.

Gutman, A. B., Yu, T. F., and Berger, L. (1959). Tubular secretion of urate in man. Fournal of Clinical Investigation, 38, 1778.

Humphreys, D. M. (1966). Acute gout apparently precipitated by frusemide. British Medical fournal, 1, 1024.

Kerr, D. N. S., and Robson, A. O. (1965). Frusemide. Practitioner, 194, 694.

Oren, B. G., Rich, M., and Belle, M. S. (1958). Chlorothiazide (Diuril) as a hyperuricacidemic agent. Fournal of the American Medical Association, 168, 2128.

O'Sullivan, J. B. (1968). The incidence of gout and related uric acid levels in Sudbury, Massachusetts. In Population Studies of the Rheumatic Diseases, p. 371. Proceedings. 3rd International Symposium, New York, June 5-10, 1966. Ed. by P. H. Bennett and P. H. N. Wood. Excerpta Medica, Amsterdam.

Popert, A. J., and Hewitt, J. V. (1962). Gout and hyperuricaemia in rural and urban populations. Annals of the Rheumatic Diseases, 21, 154.

Schmidt-Nielsen, B. (1958). Urea excretion in mammals. Physiological Reviews, 38, 139.

Seegmiller, J. E. (1967). Significance of hyperuricemia. Medical Annals of the District of Columbia, 36, 215.

Smyth, C. J., Stecher, R. M., and Wolfson, W. Q. (1948). Genetic and endocrine determinants of the plasma urate level. Science, 108, 514.

Warshaw, L. J. (1960). Acute attacks of gout precipitated by 
chlorothiazide-induced diuresis. Fournal of the American Medical Association, 172, 802.

Zalokar, J., Lellouch, J., Claude, J. R., and Kurtz, D. (1974). Epidemiology of serum uric acid and gout in Frenchmen. Fournal of Chronic Diseases, 27, 59.
Requests for reprints to Dr. C. J. Bulpitt, Department of Medical Statistics and Epidemiology, London School of Hygiene and Tropical Medicine, Keppel Street, London WC1E 7HT. 